\title{
Fool's Gold? Assessing the Impact of the Value of Airline Loyalty Programs on Brand Equity Perceptions and Share of Wallet
}

Article in Cornell Hospitality Quarterly · March 2015

DOI: $10.1177 / 1938965514564213$

CITATIONS

4

4 authors, including:

\section{Clay Voorhees}

Michigan State University

35 PUBLICATIONS 854 CITATIONS

SEE PROFILE
READS

82

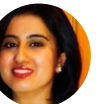

Praneet Randhawa

University of Baltimore

6 PUBLICATIONS 21 CITATIONS

SEE PROFILE 


\title{
Fool's Gold? Assessing the Impact of the Value of Airline Loyalty Programs on Brand Equity Perceptions and Share of Wallet
}

Cornell Hospitality Quarterly

20I5, Vol. 56(2) 202-212

(C) The Author(s) 2015

Reprints and permissions:

sagepub.com/journalsPermissions.nav DOI: $10.1177 / 1938965514564213$

cqx.sagepub.com

\author{
Clay M. Voorhees', Ryan C. White', Michael McCall', and Praneet Randhawa ${ }^{3}$
}

\begin{abstract}
Despite substantial investments in loyalty programs, hospitality industry managers and marketers are given little evidence regarding the loyalty programs' overall effectiveness in driving consumer spending. This study of an airline's loyalty program demonstrates the importance of brand power and the influence of customer characteristics on the value the loyalty program has on share of wallet. While loyalty programs in their current form do provide some brand building benefits, their effect on share of wallet is significantly stronger for price-seeking customers who are prone to brand switching. In contrast, the loyalty program has no direct effect on share of wallet for brand-loyal customers. The study also demonstrates the power of high-equity brands, which enjoy differentially higher gains from their loyalty programs than low-equity brands can experience. Thus, this airline's loyalty program does provide some benefit, but perhaps not in the way the company wishes. The industry should consider their customers' permanent characteristics (i.e., their level of loyalty or willingness to switch brands) and revise these programs to ensure that they continue to deliver value to a firm's best customers rather than just attracting brand switching customers.
\end{abstract}

\section{Keywords}

customer loyalty; loyalty program; brand equity; share of wallet; brand switching; reward program

Loyalty marketing has grown into a six-billion-dollar industry as firms have spent millions to upgrade their frequent guest reward programs. These loyalty investments have resulted in sharp increases in consumer participation in rewards programs, evidenced by the more than 2.8 billion enrollments in the United States alone (Hlavinka and Sullivan 2011). Despite these investments, several academics have called the design of traditional loyalty programs into question by suggesting that they may be "betraying" the firms that created them (Nunes and Drèze 2006) and even going so far as to label them "surprisingly ineffective" (Dowling and Uncles 1997) and "shams" (Shugan 2005).

To analyze loyalty programs' performance (cf. Gupta and Zeithaml 2006), researchers have begun to investigate the antecedents to and boundary conditions of loyalty program effectiveness. Mattila (2006), for instance, demonstrated that developing affective commitment to the brand can be an effective way to improve perceptions of loyalty programs. Moreover, researchers have investigated the relationship between the program and customer loyalty by considering the effects of customer involvement ( $\mathrm{Yi}$ and Jeon 2003) and attitudinal loyalty (Wirtz, Mattila, and Lwin 2007), as well as household characteristics, store characteristics, and loyalty program design characteristics (Leenheer et al. 2007). Despite considerable interest, our understanding of how-and whether-loyalty programs influence customer loyalty remains tenuous (Henderson, Beck, and Palmatier 2011; Leenheer et al. 2007). We do not know when these programs actually work (Bolton, Kannan, and Bramlett 2000; Dowling and Uncles 1997), and the contributing factors to a loyalty program's success have yet to be identified (McCall and Voorhees 2010) despite the vast number of customers participating in loyalty programs (DeKay, Toh, and Raven 2009; A. Smith and Sparks 2009).

The critical issue involves how the perceived value that loyalty programs offer customers interacts with two fundamental concepts of strategic marketing - brand equity and market segmentation. Thus, even as hospitality managers use loyalty programs to pursue their strategic marketing goals, little is known about the relationship that loyalty programs have with the "cornerstone" of marketing (Berry

'Michigan State University, East Lansing, USA

${ }^{2}$ Winona State University, MN, USA

${ }^{3}$ University of Baltimore, MD, USA

\section{Corresponding Author:}

Clay M. Voorhees, Department of Marketing, Eli Broad College of Business, Michigan State University, 632 Bogue Street, N370 North Business Complex, East Lansing, MI 48824, USA.

Email: voorhees@bus.msu.edu 


\section{Exhibit 1:}

\section{Conceptual Model.}

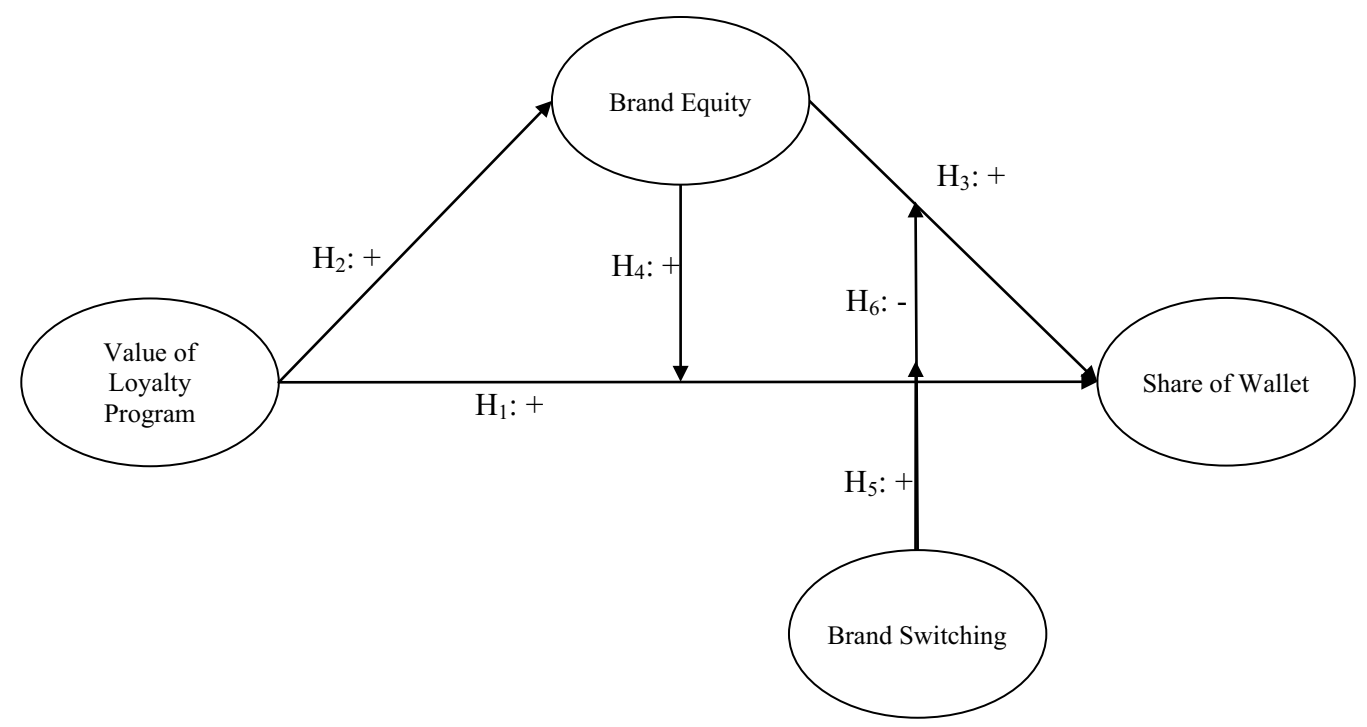

2000), the firm's brand equity. Furthermore, while market segmentation has provided the foundation of strategic marketing for over half a century (cf. W. R. Smith 1956), practitioners typically either forgo segmenting loyalty program customers or segment them solely by purchase history (Berman 2006). This emphasis is echoed by academics as efforts to segment loyalty program members have often neglected to make the distinction between customer states and traits and avoided invariant customer predispositions in favor of situation specific attitudes and behaviors, such as the attractiveness of alternatives, satisfaction, and trust (Hansen, Deitz, and Morgan 2010).

As a result, little is known about how the consistent, stable characteristics of customers influence consumer choice behavior, most notably, the customers' brand switching behavior (Seetharaman and Chintagunta 1998). These characteristics undoubtedly influence the effectiveness of loyalty programs, particularly in relation to how marketers can use brand switching proclivities to segment consumers (Bock and Uncles 2002). Given that one goal of these programs is to attract customers, this study examines the intersection between brand switching and participation in loyalty programs by examining how brand equity and customer differences, such as differences in brand switching, may influence the effectiveness of loyalty programs (see Exhibit 1).

\section{Conceptual Background}

For any loyalty program to be effective at increasing customer loyalty, customers have to value that program (Bolton, Kannan, and Bramlett 2000; Kumar and Shah 2004; O'Brien and Jones 1995; Yi and Jeon 2003). By this notion, customers have to perceive value in the loyalty program (Zeithaml 1988) for them to choose to participate in it. This notion is consistent with Sheth, Newman, and Gross's (1991) theory of consumer choice values, where consumer choice behavior is guided by three axioms: (1) consumer choice is a function of multiple consumption values, (2) the consumption values make differential contributions in any given choice situation, and (3) the consumption values are independent. Sheth and his colleagues specified five consumption values that apply when a consumer is making a product or service choice, namely, functional value, social value, emotional value, epistemic value, and conditional value. These multiple values in turn independently and differentially influence a consumer's choice of the most valuable alternative. This theory applies to all individual, systematic, and volitional consumer choices and is therefore appropriate in the context of loyalty programs.

Sheth, Newman, and Gross's (1991) framework of five consumer values aligns closely with the independent value offerings provided through most rewards programs, as follows. Functional value can be thought of as the perceived utility acquired from the performance of the loyalty program's attributes, such that a consumer may perceive higher value if the loyalty program is reliable or affordable. The social value is the perceived utility acquired from the loyalty program's association with one or more specific social groups, such that a consumer may perceive higher value if the loyalty program is associated with a desirable social group. The emotional value is the perceived utility acquired from the program's ability to engender affective states, such that a consumer may perceive higher value if the loyalty program creates positive emotions. The epistemic value is 
the perceived utility acquired from the loyalty program's ability to pique curiosity, provide novelty, or satisfy a desire for knowledge, such that a consumer may perceive higher value if the loyalty program affords new experiences, such as access to VIP areas like the Delta Air Lines' Sky Club lounge. Finally, the conditional value is the perceived utility acquired from the loyalty program as a result of a specific situation or set of circumstances facing the consumer, such that a consumer may perceive higher value if the loyalty program offers immediate benefits, such as discounts on shopping purchases.

The above examples show how loyalty programs could provide value and increase a customer's propensity to participate in the program through purchasing from the firm. Therefore, we expect the following:

Hypothesis 1 (H1): Customer perceptions of the value of a loyalty program have a positive and direct effect on share of wallet.

Customer perceptions of the value of a loyalty program should not only affect the amount of money the customer spends with the firm, but also influence the level of equity associated with the brand. Keller $(1993,8)$ defines brand equity as "the differential effect of brand knowledge on the consumer's response to the marketing of the brand." Under Keller's (1993) definition, brand knowledge has a variety of linked associations that result in positive brand equity when a consumer responds more favorably to the marketing mix elements of the brand than to the same marketing mix elements that have some other name (or no name). For this reason, marketers seek to increase the consumer's brand knowledge through increasing brand awareness and brand image, with a goal of increasing brand equity.

One method Keller (1993) proposes to enhance brand evaluations is to make marketing mix investments that increase brand awareness by increasing the customer's exposure to the brand (Alba, Hutchinson, and Lynch 1991). Furthermore, brand equity should also increase to the extent that supporting marketing program elements can increase the favorability, strength, and distinctiveness of the brand image. As a result, marketing mix elements that can simultaneously increase brand awareness and differentiate the brand's image can have a profound impact on brand equity.

In line with this logic, empirical research has confirmed the effects of marketing mix elements, such as store image, advertising spending, and price deals on brand familiarity and associations (Yoo, Donthu, and Lee 2000). Most critically, according to Lassar, Mittal, and Sharma (1995), this brand equity rests on consumers' perception of the brand (and its associated utility) rather than any objective indicators. Lassar and colleagues define value as "the perceived brand utility relative to its costs, assessed by the consumer and based on simultaneous considerations of what is received and what is given up to receive it" (p. 13).

Extending this reasoning beyond the core marketing mix and perceived value, we suggest that additional elements, such as a customer loyalty program, may also provide promote top-of-mind awareness as well as offer customers a differential advantage and high value for doing business with a brand. With regard to loyalty programs, when customers perceive value in a loyalty program, this value can be transferred to the parent brand. We therefore expect the following:

Hypothesis 2 (H2): Customer perceptions of the value of a loyalty program have a positive, direct effect on customer perceptions of brand equity.

High brand equity confers many benefits, including the most important one, higher share of wallet. Other researchers have explored the numerous channels to brand equity and the resulting benefits (for example, see Leone et al. 2006; Park, Jaworski, and MacInnis 1986; Srivastava and Reibstein 2005; Webster 2000). We follow Erdem and Swait's (1998) idea that the brand is a signal to consumers of the value of the product or service that influences consumer choice through inclusion in consumer decision-making heuristics, which are used as shorthand for processing brand information. High brand equity means that the brand is not only salient but also that its benefits and information are relatively easy to understand (Bettman, Johnson, and Payne 1991). In short, by signaling value, the brand reduces the cost of acquiring information and the perceived risk of making a purchase. As a consequence, customers will prefer the brand to which they attribute the highest expected value. Therefore, we anticipate the following:

Hypothesis 3 (H3): Customer perceptions of brand equity have a positive and direct effect on share of wallet.

In addition to its direct effects, brand equity can potentially interact with other marketing investments to affect consumer spending. Most to the point here, it is likely that marketing mix investments may have a stronger effect for stronger brands due to a phenomenon known as "double jeopardy." McPhee (1963) first noted this effect, which occurs because smaller brands tend to have fewer buyers and those fewer buyers have lower purchase frequencies. Conversely, larger brands tend to have more buyers with higher purchase frequencies.

Brand equity contributes to this double jeopardy effect because brands with high brand equity have high customer "mind share," which contributes to market share (Berry 2000). Using McPhee's (1963) original reasoning (cf. Ehrenberg, Goodhardt, and Barwise 1990; Sharp and Sharp 
1997), this effect occurs because consumers will have greater familiarity with the high-equity brand, thus increasing the effects of other evaluations of the firm. The double jeopardy effects are so profound that consumers are unlikely to patronize particularly unknown brands regardless of their perceptions of other features of the firm, including the value of the loyalty program. Therefore, brand equity's role as a signal of value results in synergistic interactions with consumers' perceptions of elements of the marketing mix, notably the loyalty program, to the extent that the effects of marketing mix investments are stronger for higher equity brands. Thus, we expect that the following:

Hypothesis 4 (H4): Customer perceptions of brand equity will positively moderate the effects of customer perceptions of the value of a loyalty program to the extent that the effects of the perceived value of a loyalty program will be stronger when brand equity evaluations are high.

Research has demonstrated that routines may induce feelings of monotony and boredom in some individuals, which may lead them to try new products or brands (Menon and Kahn 1995). Moreover, research on brand switching suggests that consumers can be viewed as lying along a loyalty continuum with regard to loyalty to a specific brand (Uncles, Dowling, and Hammond 2003).

Uncles, Dowling, and Hammond (2003) proposed that the loyalty continuum has endpoints of brand commitment and brand buying, with a midpoint of brand acceptance. In this continuum, consumers who are brand committed are low on brand switching, because they value the psychological and social benefits of the brand more than the specific product or service. At the other end of the continuum are promiscuous consumers, who are willing to switch to any brand, usually based on economic considerations. Needless to say, these brand switchers demonstrate low levels of brand loyalty. In this manner, consumers' stable overall individual differences with regard to brand switching are reflected in loyalty behavior, and consumers can be characterized as having trait differences with regard to purchase behavior (Mischel and Shoda 1995).

Marketers are well aware of consumers' differential brand switching behavior, as their firms have invested heavily in their loyalty programs with the hope of retaining their customers who avoid brand switching and attracting customers who are prone to brand switching. One effort to attract the brand switchers is found in airline loyalty programs that involve alliances with other brands. According to Lemon and Wangenheim (2009), the alliance of one firm with partners, including other airlines and various product and service purveyors, leads to an increase in cross-buying, but also helps retain the patronage of the brand switching customers.
The brand switchers present a particular conundrum for marketers because those customers may make their purchase decisions not only based on the economic incentives offered by a firm but also because of their desire to experience new brand. This is why we believe the brand switching customers will respond to incentives like those offered in a loyalty program with multiple partners and alter their spending accordingly. Therefore, because brand switching customers place more weight on both the economic incentives and promotional perks, together with the availability of different brand options provided by firms, we expect the following:

Hypothesis 5 (H5): Brand switching will moderate the effects of customer perceptions of the value of the loyalty program on share of wallet to the extent that the perceived value of the loyalty program will have a significantly stronger effect for customers high in brand switching than low in brand switching.

However, the premium that low brand switching consumers place on risk reduction through establishing trusting relationships with a brand relegates incentive-based marketing investments, such as rewards programs and promotions, to a secondary role in the purchase decision. Thus, we hypothesize as follows:

Hypothesis 6 (H6): Brand switching will moderate the effects of brand equity on share of wallet to the extent that brand equity will have a significantly weaker effect for customers high in brand switching than low in brand switching.

\section{Method and Results}

We tested a particular airline's loyalty program for this research following Liu and Yang (2009), because the similarity of the loyalty programs between airlines helps control for the effects of different loyalty program designs. We note, however, that one factor differentiates airline loyalty programs from each other, and that is their alliance partners, for example, the United Star Alliance. We will not mention which airline we tested, but to obtain responses, we asked consumers to evaluate the airline with which they had most recently traveled, and received 746 responses. We then reduced the sample only to consumers who indicated that they were enrolled in the test airline's loyalty program, leaving 284 consumers who provided data suitable for analysis.

The sample was evenly divided between men and women, and the average age was 43.32 years. The respondents were preponderantly Caucasian (82.6\%), with small percentages of African-American, Hispanic, and Asian-American participants. The sample was generally well educated, as 95.7 percent had completed at least some college, and the median household income range was $\$ 80,000$ to $\$ 99,000$. 


\section{Exhibit 2:}

Scale Statistics and Correlations.

\begin{tabular}{|c|c|c|c|c|c|c|c|c|c|c|}
\hline \multirow[b]{2}{*}{ Variables } & \multirow[b]{2}{*}{ M } & \multirow[b]{2}{*}{$S D$} & \multirow[b]{2}{*}{ CR } & \multirow[b]{2}{*}{ AVE } & \multicolumn{6}{|c|}{ Correlations } \\
\hline & & & & & I & 2 & 3 & 4 & 5 & 6 \\
\hline I. Perceived value of the loyalty program & 7.49 & 2.05 & 0.91 & 0.78 & .88 & & & & & \\
\hline 2. Brand equity & 6.67 & 2.91 & 0.96 & 0.85 & $.54 *$ & .92 & & & & \\
\hline 3. Share of wallet & 55.69 & 25.94 & - & - & $.42^{*}$ & $.52 *$ & - & & & \\
\hline 4. Service quality & 7.21 & 2.23 & 0.96 & 0.89 & $.27^{*}$ & $.60 *$ & $.28 *$ & .94 & & \\
\hline 5. Physical environment quality & 6.88 & 1.99 & 0.91 & 0.78 & $.40^{*}$ & $.59 *$ & $.29 *$ & $.65^{*}$ & .88 & \\
\hline 6. Brand switching & 6.49 & 1.97 & 0.83 & 0.55 & $-.07 *$ & $-.18 *$ & $-.13^{*}$ & $-.03 *$ & $-.01 *$ & .74 \\
\hline
\end{tabular}

Note. AVE and CR estimates are not calculated for Share of Wallet as it is a single item scale; The square root of the AVEs are provided on the diagonal in bold italics. $C R=$ construct reliability; $A V E=$ average variance extracted. $*_{p}<.05$.

\section{Measurement}

Existing multiple item-scales were used to operationalize all the variables, except for the share-of-wallet variable, which was measured with a single indicator. All other variables were measured using 11-point Likert-type scales (as shown in the appendix). In addition to the constructs in the research model, two control variables, service quality and physical environment quality, were also included in the analysis. Service quality is described as a form of attitude that originates from the comparison of expectations with performance (Cronin and Taylor 1992; Parasuraman, Zeithaml, and Berry 1988). Physical environment is shown to affect consumers' behavior (Bitner 1992), which is why service firms use tangible cues to reach consumers and to make up for the lack of tangible contact in a service environment (Hightower, Brady, and Baker 2002). Because both service quality and physical environmental quality influence firm performance (Hightower, Brady, and Baker 2002; Parasuraman, Zeithaml, and Berry 1988; Zeithaml, Berry, and Parasuraman 1996), we included these control variables to provide a more conservative assessment of the effects of brand equity and value of the loyalty program on share of wallet.

Based on Zeithaml's (1988) conceptualization, we define perceived value of the loyalty program as an assessment of the overall utility of the service based on customer perceptions of what is received and what is given. Furthermore, we adapted a three-item scale to assess the perceived value of a loyalty program (based on O'Brien and Jones 1995; Voorhees 2006).

We used four items to test brand equity, which is defined as the differential effect of brand knowledge on consumers' response to the marketing of the brand (Keller 1993). These items are drawn from the scale created by Yoo and Donthu (2001), which integrated and extended the conceptual discussions surrounding the concept of brand equity by developing a multi-item scale that incorporated both Keller's (1993) and Aaker's (1991) conceptualizations of brand equity.
Share of wallet was measured by having respondents estimate the percentage of their air travel that they book with the airline in question.

Brand switching was measured by adapting four items from the scale introduced by Raju (1980) and the exploratory acquisition of products scale introduced by Baumgartner and Steenkamp (1996).

Service quality is measured using three items adapted from Brady and Cronin (2001b) and Oliver (1997), providing a summary evaluation of the overall service quality offered by a firm. Similarly, three items from Brady and Cronin (2001b) assessed the overall quality of the physical environment (the airplanes' interiors).

\section{Measurement Testing}

A measurement model containing all variables was estimated, where all items were forced to load on their respective factors. The measurement model fit the data well, $\chi^{2}(d f=$ $133)=494.13$, comparative fit index $(\mathrm{CFI})=0.95$, nonnormed fit index $(\mathrm{NNFI})=0.94$, standardized root mean square residual $($ SRMR $)=0.07$. Convergent validity was confirmed, as an examination of the $t$ values revealed that all items loaded highly and significantly on their intended variable and the average variance extracted for each multiitem construct exceeded 0.50 (Fornell and Larcker 1981). The square root of the average variance extracted for each construct also exceed the correlation with all other constructs in the research model, providing evidence of discriminant validity (Fornell and Larcker 1981). Finally, construct reliabilities for all scales exceed 0.80 . Scale statistics are provided in Exhibit 2.

\section{Hypothesis Testing}

After the measurement assessment, a moderated structural equation model was estimated to test $\mathrm{H} 1, \mathrm{H} 2, \mathrm{H} 3$, and $\mathrm{H} 4$, all of which were supported by the data (see Exhibit 3). To estimate the moderated structural equation model with an 


\section{Exhibit 3:}

\section{Results of Hypothesis Testing (HI to H4).}

\begin{tabular}{llcc}
\hline Hypothesized Paths & CS & $R^{2}$ & Hypothesis Testing \\
\hline CI: Service quality $\rightarrow$ Brand equity & $0.35^{* *}$ & .54 & - \\
C2: Physical environment quality $\rightarrow$ Brand equity & $0.17^{* *}$ & & - \\
H2: Perceived value of a loyalty program $\rightarrow$ Brand equity & $0.41^{* *}$ & & Supported \\
CI: Service quality $\rightarrow$ Share of wallet & $-0.02^{* *}$ & .36 & - \\
C2: Physical goods quality $\rightarrow$ Share of wallet & $0.06^{* *}$ & & - \\
HI: Perceived value of a loyalty program $\rightarrow$ Share of wallet & $0.14^{* *}$ & & Supported \\
H3: BE $\rightarrow$ Share of wallet & $0.52^{* *}$ & & Supported \\
H4: VLP $\times$ BE $\rightarrow$ Share of wallet & $0.19^{* *}$ & Supported \\
\hline
\end{tabular}

Note. $\mathrm{Cl}$ and $\mathrm{C} 2$ refer to the effects of the control variables on both dependent variables. $\mathrm{CS}=$ completely standardized coefficient; VLP $=$ value of the loyalty program; $\mathrm{BE}=$ brand equity.

${ }^{*} p<.05 .{ }^{*} p<.01$.

endogenous interaction, we followed the recommendations of Ping (2009), and correlations between the interaction term and the perceived value of the loyalty program construct and the structural disturbance for the brand equity construct were specified. The moderated structural equation model provided good fit to the data, $\chi^{2}(d f=87)=316.27$, $\mathrm{CFI}=0.97, \mathrm{NNFI}=0.96, \mathrm{SRMR}=0.08$. Both control variables, service quality $(\beta=.35)$ and physical goods quality $(\beta$ $=.17)$, significantly affected perceptions of brand equity $(p$ $<.01$ ), but neither had a significant effect on share of wallet. $\mathrm{H} 1$ and $\mathrm{H} 2$ were supported, as the value of the loyalty program significantly affected share of wallet $(\beta=.14, p<.05)$ and brand equity $(\beta=.41, p<.01)$. H3 was also supported as brand equity also affected share of wallet $(\beta=.52, p<$ .01 ). Finally, the endogenous interaction effect between the perceived value of the loyalty program and brand equity on share of wallet was positive and significant $(\beta=.19, p<$ .05 ), thus supporting H4. In all, the control and predictor variables explained 54 percent of the variance in brand equity and 36 percent of the variance in share of wallet.

Finally, a series of multi-group structural equation model comparisons were conducted to assess differences in the path strengths for consumers who scored low, and those who scored high in brand switching, as proposed in $\mathrm{H} 5$ and H6. We divided the groups using a median split and then conducted nested model comparisons to determine whether the strength of the perceived value of the loyalty program to share of wallet (H5) and brand equity to share of wallet (H6) paths differed between the two groups.

As a test of $\mathrm{H} 5$, we found that constraining the path from perceived value of the loyalty program to share of wallet to be equal for the two consumer groups did not offer significantly worse fit to the data, $\chi_{\text {diff }}^{2}(1)=.04, p>.05$, than the unconstrained model. This result is not surprising given the relative ineffectiveness of the chi-square likelihood ratio test to detect group differences when the sample size is small (Qureshi and Compeau 2009). Therefore, an examination of the standardized individual path strengths across the two groups is important. The perceived value of the loyalty program to share of wallet path was not significant for consumers that were low in brand switching $(\beta=.11, p>$ $.05)$, but the perceived value of the loyalty program to share of wallet path was significant for consumers that were high in brand switching $(\beta=.20, p<.01)$. These results provide support for $\mathrm{H} 5$, as a review of the path coefficients revealed that the perceived value of the loyalty program had a significantly stronger impact on share of wallet for consumers high in brand switching than for consumers low in brand switching even though the multi-group test could not validate a significant change in model fit.

The same multi-group analysis procedure was used to test H6, but this time the results revealed that the fit of the model that constrained the path from brand equity to share of wallet to be equal for the two consumer groups offered significantly worse fit to the data, $\chi_{\text {diff }}^{2}(1)=4.10, p<.05$, than the unconstrained model. This result and an examination of the standardized individual path strengths across the two groups provides support for H6. That is, the path from brand equity to share of wallet for consumers scoring low in brand switching was stronger $(\beta=.62, p<.01)$ than that same path for consumers high in brand switching $(\beta=.38$, $p<.01)$.

\section{Discussion}

The results provide a more complete understanding of the interplay between loyalty programs, brand equity, and customer traits, as well as the resulting effects on consumer spending. For this airline's loyalty program, we demonstrate that its perceived value enhances consumer spending both directly and indirectly via perceptions of brand equity. This finding provides evidence that offering consumers a valuable loyalty program can benefit a firm. This involves creating "velvet handcuffs," as well as increasing brand equity and its associated benefits. Building on these main effects, our analysis demonstrates that the direct effect of 
the perceived value of a loyalty program on share of wallet is significant only for high-equity brands. This suggests that any increase in share of wallet due to the perceived value of a loyalty program is entirely indirect for low-equity brands. Consequently, we conclude that the airline industry's loyalty programs in their current form are essentially ineffective at driving consumer spending without support from a valued brand name.

We also found that loyalty programs appeal to brand switchers. Our contingency tests reveal that the perceived value of a loyalty program has a stronger effect on share of wallet for consumers that have a high predisposition to switch brands. However, brand equity is the path to the wallet for consumers that have a low predisposition to switch brands. This finding adduces the "fool's gold" found in our title. Despite their shine, loyalty programs in the airline industry may effectively be fool's gold, because they directly generate spurious loyalty (from the brand switchers), but can only generate true long-term loyalty indirectly (from the brand loyalists) as a function of brand equity.

\section{Theoretical Implications}

This study is the first that we have seen that directly links the perceived value of the loyalty program with brand equity and ultimately share of wallet. Although O'Brien and Jones (1995) outlined the attributes valued in a loyalty program, there have been few if any direct tests of the effects of loyalty program value on both attitudinal and behavioral consequences (rather than simply whether a program exists or not). Having examined the matter of value, this research demonstrates the need for research not only on the impact of program membership and status on consumption, but also on consumer attitudes within the program. Future research can build on this work in an effort to empirically identify how managers can improve perceptions of the value of a loyalty program and the impact of such initiatives on a broader array of attitudinal assessments of the firm.

More broadly, this study speaks directly to the call by co-authors McCall and Voorhees (2010) for more research on customer loyalty, a topic they have studied in considerable depth. Most research on customer behavior has examined models that link the customer experience, particularly service quality and value, on purchase intentions (notably, Cronin, Brady, and Hult 2000). Our research extends findings from these initial models by demonstrating the complementary role of the perceived value of a loyalty program in predicting customers' purchase intentions after accounting for the baseline effects of goods and service quality.

Along that line, Grewal and Levy (2007) call for more research that examines how loyalty programs influence customer behavior and under what conditions firms should use loyalty programs, and Mägi (2003) calls for the incorporation of variety seeking into models which examine repeat-purchase behavior. Our research answers these calls by providing evidence of the process by which the perceived value of a loyalty program affects share of wallet, as well as two conditions under which programs may be particularly effective, or not so, given customers with differing brand seeking tendencies. Future research can build on these results to examine whether further investment in loyalty programs is worth the cost. Given our results, it is quite possible that loyalty programs for lesser brands may not provide enough of an increase in customer spending to justify their expense when other marketing mix elements may be more successful at generating enduring customer loyalty.

\section{Managerial Implications}

Perhaps the most important implication of this study is the importance of connecting the loyalty program benefits with the brand. Managers need to properly benchmark the strength of a brand, given that customers' perceptions of brand equity not only have direct effects on their spending, but also moderate the effectiveness of the loyalty program's perceived value in driving share of wallet. We now know that stronger brands stand to gain more from their loyalty programs than do weaker brands. For weaker brands, the perceived value of the loyalty program had no direct effects on share of wallet. Instead, the only benefit of offering a loyalty program flows to a weak brand indirectly via brand equity. By implication, the "family level" effects of programs that provide rewards across several brands, as in the case of hotel groups or an airline alliance, probably are largely driven by the stronger brands in the family or alliance.

Due to the importance of brand equity in directly affecting share of wallet and moderating the impact of the perceived value of the loyalty program, managers should maintain an emphasis on improving brand perceptions and ensuring that the loyalty program offers solid value. Our results suggest that the provision of a highly valued loyalty program can increase brand equity. This is true even when we control for the effects of service quality and physical goods quality. For strong brands, loyalty programs not only influence consumer purchase behavior under certain conditions, but can also bolster consumer attitudes toward the brand. With this in mind, our results suggest two approaches. Firms need to focus on differentiating their loyalty programs from those of the competition and also on increasing the value provided by their loyalty programs. One way to upgrade program value and evaluation is to position a program as being a privilege (Winer 2001). Managers must also work to provide meaningful and customized rewards that match their settings. These simple adjustments can lead to increases in both consumer spending and referral behavior (Kivetz and Simonson 2003). 
Regardless of a firm's loyalty strategies, their impact on consumer spending will vary according to the consumers' characteristics (Meyer-Waarden 2008). In particular, loyalty programs are notably ineffective at increasing share of wallet for consumers who are predisposed to be loyal to brands. However, improvements in the perceived value of a loyalty program will attract the brand switchers, resulting directly in increases in spending among a firm's least desirable customers, who are just shopping around. Consequently, when improved loyalty programs seem to be drawing in more supposedly loyal customers, a firm is unlikely to convert these customers into loyalists unless the firm can find a way to provide continued value. That seems unlikely given the competitive nature of the service industry's loyalty programs. Although that situation seems disheartening, our findings underscore the importance of better consumer research and segmentation within loyalty programs to ensure that customer rewards are aligned with the needs of the most desirable customers.

The push toward program segmentation argues for a need for better differentiation of loyalty programs to ensure that all customers recognize the value that is offered by a particular program relative to the competition. Just as a brand would never launch a product without adequate differentiation from the competition, loyalty programs need to be positioned against the competitive alternatives. Program elements that might accomplish this include differential offerings for program members, intangible aspects that are hard to duplicate, and engagement opportunities.

In short, managers need to structure their loyalty programs to better segment their customer bases and to differentiate their programs from their competition. We now know that any improvements to a loyalty program will have stronger effects for high-equity brands. That means that managers of low-equity brands must set their expectations accordingly when making improvements to their program.

As a final note, as this study examined an airline loyalty program, we need further study to determine whether the findings of this study also apply to loyalty programs in the hotel sector. According to the results of Dekay, Toh, and Raven's (2009) study, most frequent travelers are not only more aware of airline loyalty programs, but they also prefer the airline programs to those offered by hotels. This suggests that travelers may be more willing to enroll for hotel loyalty programs that have tie up with airline companies. Given that frequent travelers have higher preference for airline loyalty programs, it would be fruitful to investigate whether hotel loyalty programs can gain popularity by joining hands with airlines and in turn help increase the airline loyalty program value proposition by providing upgrades in the form of hotel amenities and facilities. Then again, as the airlines alter their programs to provide rewards for dollars spent rather than miles traveled, the balance between the airline programs and the hotel programs may be altered.

\section{Appendix}

\section{Measurement Items}

All items are scored using an 11-point Likert-type scale, where $0=$ Strongly Disagree and $10=$ Strongly Agree unless otherwise noted.

Perceived value of a loyalty program

This service provider has an excellent loyalty program.

The benefits offered by this service provider's loyalty programs are worthwhile.

The time it takes to earn rewards with this service provider's loyalty programs is acceptable.

Brand equity

Even if a competitor offers the same service as this provider, I would prefer to do business with this provider.

If there is a competitor as good as this provider, I still prefer this provider.

If another brand is not different from this company in any way, it seems smarter to purchase this brand.

I would be willing to pay more for the goods and services from this provider than for similar goods and services offered by other companies.

Service quality

I would say that this service firm provides superior service. 


\section{Appendix (continued)}

Constructs

Standardized Loading

Physical environment quality

The amenities on this airline's planes are high quality. .88

This airline's planes are excellent.

.92

.85

The interiors of this airline's planes are some of the best available.

.82

.78

.70

.66

I would rather try something new than stick with a brand I usually buy.

Share of wallet

What percentage of your air travel do you book with (focal airline)? (0\% to $100 \%)$

1.00

\section{Declaration of Conflicting Interests}

The author(s) declared no potential conflicts of interest with respect to the research, authorship, or publication of this article.

\section{Funding}

The author(s) received no financial support for the research, authorship, or publication of this article.

\section{References}

Aaker, D. A. 1991. Managing brand equity: Capitalizing on the value of a brand name. New York: Free Press.

Alba, J. W., J. W. Hutchinson, and J. G. Lynch, Jr. 1991. Memory and decision making. In Handbook of consumer behavior, ed. T. S. Robertson and H. H. Kassarjian, 1-49. Englewood Cliffs: Prentice Hall.

Baumgartner, H., and J. B. E. M. Steenkamp. 1996. Exploratory consumer buying behavior: Conceptualization and measurement. International Journal of Research in Marketing 13 (2): 121-37.

Berman, B. 2006. Developing and effective customer loyalty program. California Management Review 49 (1): 123-48.

Berry, L. L. 2000. Cultivating service brand equity. Journal of the Academy of Marketing Science 28 (1): 128-37.

Bettman, J. R., E. J. Johnson, and J. W. Payne. 1991. Consumer decision making. In Handbook of consumer behavior, ed. T. S. Robertson and H. H. Kassarjian, 50-84. Englewood Cliffs: Prentice Hall.

Bitner, M. J. 1992. Servicescapes: The impact of physical surroundings on customers and employees. Journal of Marketing 56 (April): 57-71.

Bock, T., and M. Uncles. 2002. A taxonomy of differences between consumers for market segmentation. International Journal of Research in Marketing 19 (3): 215-24.

Bolton, R. N., P. K. Kannan, and M. D. Bramlett. 2000. Implications of loyalty program membership and service experiences for customer retention and value. Journal of the Academy of Marketing Science 28 (1): 95-108.

Brady, M. K., and J. J. Cronin, Jr. 2001. Some new thoughts on conceptualizing perceived service quality: A hierarchical approach. Journal of Marketing 65 (3): 34-49.
Cronin, J. J., Jr., M. K. Brady, and G. T. M. Hult. 2000. Assessing the effects of quality, value, and customer satisfaction on consumer behavioral intentions in service environments. Journal of Retailing 76 (2): 193-218.

Cronin, J. J., Jr., and S. A. Taylor. 1992. Measuring service quality: A reexamination and extension. Journal of Marketing 56 (3): 55-68.

DeKay, F., R. S. Toh, and P. Raven. 2009. Loyalty programs: Airlines outdo hotels. Cornell Hospitality Quarterly 50 (3): 371-82.

Dowling, G. R., and M. D. Uncles. 1997. Do customer loyalty programs really work? Sloan Management Review 38 (4): 71-82.

Ehrenberg, A. S. C., G. J. Goodhardt, and T. P. Barwise. 1990. Double jeopardy revisited. Journal of Marketing 54 (3): $82-91$.

Erdem, T., and J. Swait. 1998. Brand equity as a signaling phenomenon. Journal of Consumer Psychology 7 (2): 131-57.

Fornell, C., and D. F. Larcker. 1981. Evaluating structural equation models with unobservable variables and measurement error. Journal of Marketing Research 18 (1): 39-50.

Grewal, D., and M. Levy. 2007. Retailing research: Past, present, and future. Journal of Retailing 83 (4): 447-64.

Gupta, S., and V. Zeithaml. 2006. Customer metrics and their impact on financial performance. Marketing Science 25 (6): 718-39.

Hansen, J. D., G. D. Deitz, and R. M. Morgan. 2010. Taxonomy of service-based loyalty program members. Journal of Services Marketing 24 (4): 271-82.

Henderson, C., J. T. Beck, and R. W. Palmatier. 2011. A review of the theoretical underpinnings of loyalty programs. Journal of Consumer Psychology 21 (3): 256-76.

Hightower, R., M. K. Brady, and T. L. Baker. 2002. Investigating the role of the physical environment in hedonic service consumption: An exploratory study of sporting events. Journal Business Research 55:697-707.

Hlavinka, K., and J. Sullivan. 2011. The billion member march: The 2011 Colloquy loyalty census. Colloquy Talk, April, 1-20.

Keller, K. L. 1993. Conceptualizing, measuring, and managing customer-based brand equity. Journal of Marketing 57 (1): $1-22$. 
Kivetz, R., and I. Simonson. 2003. The idiosyncratic fit heuristic: Effort advantage as a determinant of consumer response to loyalty programs. Journal of Marketing Research 40 (4): 454-67.

Kumar, V., and D. Shah. 2004. Building and sustaining profitable customer loyalty for the 21 st century. Journal of Retailing 80 (4): 317-30.

Lassar, W., B. Mittal, and A. Sharma. 1995. Measuring customerbased brand equity. Journal of Consumer Marketing 12 (4): $11-9$.

Leenheer, J., H. J. van Heerde, T. H. A. Bijmolt, and A. Smidts. 2007. Do loyalty programs really enhance behavioral loyalty? An empirical analysis accounting for self-selecting members. International Journal of Research in Marketing 24 (1): 31-47.

Lemon, K. N., and F. V. Wangenheim. 2009. The reinforcing effects of loyalty program partnerships and core service usage: A longitudinal analysis. Journal of Service Research $11(4): 357-70$.

Leone, R. P., V. R. Rao, K. L. Keller, A. M. Luo, L. McAlister, and R. Srivastava. 2006. Linking brand equity to customer equity. Journal of Service Research 9 (2): 125-38.

Liu, Y., and R. Yang. 2009. Competing loyalty programs: Impact of market saturation, market share, and category expandability. Journal of Marketing 73 (1): 93-108.

Mägi, A. W. 2003. Share of wallet in retailing: The effects of customer satisfaction, loyalty cards, and shopper characteristics. Journal of Retailing 79 (2): 97-106.

Mattila, A. S. 2006. How affective commitment boosts guest loyalty (and promotes frequent-guest programs). Cornell Hospitality Quarterly 47 (2): 174-81.

McCall, M., and C. Voorhees. 2010. The drivers of loyalty program success. Cornell Hospitality Quarterly 51 (1): 35-52.

McPhee, W. N. 1963. Formal theories of mass behavior. New York: Free Press.

Menon, S., and B. Kahn. 1995. The impact of context on variety seeking in product choices. Journal of Consumer Research 22 (December): 285-95.

Meyer-Waarden, L. 2008. The influence of loyalty programme membership on customer purchase behavior. European Journal of Marketing 42 (1-2): 87-114.

Mischel, W., and Y. Shoda. 1995. A cognitive-affective system theory of personality: Reconceptualizing situations, dispositions, dynamics, and invariance, in personality structure. Psychological Review 102 (2): 246-68.

Nunes, J. C., and X. Drèze. 2006. Your loyalty program is betraying you. Harvard Business Review 84 (4): 124-31.

O'Brien, L., and C. Jones. 1995. Do rewards really create loyalty? Harvard Business Review 73 (3): 75-82.

Oliver, R. L. 1997. Satisfaction: A behavioral perspective on the consumer. New York: M.E. Sharpe.

Parasuraman, A., V. A. Zeithaml, and L. L. Berry. 1988. SERVQUAL: A multiple-item scale for measuring consumer perceptions of service quality. Journal of Retailing 64 (Spring): 12-40.

Park, C. W., B. J. Jaworski, and D. MacInnis. 1986. Strategic brand concept-image management. Journal of Marketing 50 (4): $135-45$.

Ping, R. A. 2009. Estimating endogenous interactions. http:// www.wright.edu/ robert.ping/endog_ints 2 .doc.
Qureshi, I., and D. Compeau. 2009. Assessing between-group differences in information systems research: A comparison of covariance- and component-based SEM. MIS Quarterly 33 (1): 197-214.

Raju, P. S. 1980. Optimum stimulation level: Its relationship to personality, demographics, and exploratory behavior. Journal of Consumer Research 7 (3): 272-82.

Seetharaman, P. B., and P. Chintagunta. 1998. A model of inertia and variety-seeking with marketing variables. International Journal of Research in Marketing 15 (1): 1-17.

Sharp, B., and A. Sharp. 1997. Loyalty programs and their impact on repeat-purchase loyalty patterns. International Journal of Research in Marketing 14 (5): 473-86.

Sheth, J. N., B. I. Newman, and B. Gross. 1991. Why we buy what we buy: A theory of consumption values. Journal of Business Research 22 (2): 159-70.

Shugan, S. M. 2005. Brand loyalty programs: Are they shams? Marketing Science 24 (2): 185-93.

Smith, A., and L. Sparks. 2009. It's nice to get a wee treat if you've had a bad week: Consumer motivations in retail loyalty scheme points redemption. Journal of Business Research 62 (5): 542-47.

Smith, W. R. 1956. Product differentiation and market segmentation as alternative strategies. Journal of Marketing 21 (1): 3-8.

Srivastava, R., and D. J. Reibstein. 2005. Metrics for linking marketing to financial performance. MSI Special Report 05-200. Cambridge: Marketing Science Institute.

Uncles, M. D., G. R. Dowling, and K. Hammond. 2003. Customer loyalty and customer loyalty programs. Journal of Consumer Marketing 20 (4): 294-316.

Voorhees, C. M. 2006. A customer equity-based segmentation of service consumers: An application of multicriterion clusterwise regression for joint segmentation settings (Unpublished doctoral dissertation, The Florida State University, Tallahassee).

Webster, F. E., Jr. 2000. Understanding the relationships among brands, consumers, and resellers. Journal of the Academy of Marketing Science 28 (1): 17-23.

Winer, R. S. 2001. A framework for customer relationship management. California Management Review 43 (4): 89-105.

Wirtz, J., A. S. Mattila, and M. O. Lwin. 2007. How effective are loyalty reward programs in driving share of wallet? Journal of Service Research 9 (4): 327-34.

Yoo, B., and N. Donthu. 2001. Developing and validating a multidimensional consumer based brand equity scale. Journal of Business Research 52 (1): 1-14.

Yoo, B., N. Donthu, and S. Lee. 2000. An examination of selected marketing mix elements. Journal of the Academy of Marketing Science 28 (2): 195-211.

Yi, Y., and H. Jeon. 2003. Effects of loyalty programs on value perception, program loyalty, and brand loyalty. Journal of the Academy of Marketing Science 31 (3): 229-40.

Zeithaml, V. A. 1988. Consumer perceptions of price, quality, and value: A means-end model and synthesis of evidence. Journal of Marketing 52 (3): 2-22.

Zeithaml, V. A., L. L. Berry, and A. Parasuraman. 1996. The behavioral consequences of service quality. Journal of Marketing 60 (April): 31-46. 


\section{Author Biographies}

Clay M. Voorhees is an Associate Professor of Marketing at the Eli Broad College of Business at Michigan State University. He holds a Ph.D. in Business Administration from Florida State University. His research focuses on customer experience management, and customer loyalty. Clay's research has been published in the Journal of Marketing, Journal of the Academy of Marketing Science, Journal of Retailing, Cornell Hospitality Quarterly, Journal of Service Research, Strategic Management Journal, and Journal of Services Marketing. His research has been funded by the National Science Foundation, the United States Air Force Research Laboratories' Human Effectiveness Directorate, and the Marketing Science Institute.

Ryan C. White is an Assistant Professor of Marketing at Winona State University. He holds a Ph.D. in Business Administration from Michigan State University. His research centers on understanding managerial issues in services marketing and has been published in the Academy of Management Journal, Journal of Services Marketing, and Cornell Hospitality Quarterly.

Michael McCall is the Director of The School of Hospitality Business and the NAMA Endowed Professor of Hospitality
Business in the Eli Broad College of Business at Michigan State University. He earned his Ph.D. from Arizona State University and has held academic positions at Ithaca College and Cornell University. His research program focuses on the role of customer reward programs in creating customer loyalty, rebate programs, and emotional intelligence. He currently serves on the editorial boards of Journal of the Academy of Marketing Science, Cornell Hospitality Quarterly and The Journal of Hospitality and Tourism Research. His work has been funded by the National Institutes of Health and the Center for Hospitality Research and has appeared in the Journal of Applied Psychology, Cornell Hospitality Quarterly, Journal of Socio-Economics, and the International Journal of Hospitality Management.

Praneet Randhawa is an Assistant Professor of Marketing at the Merrick School of Business at University of Baltimore. He holds a Ph.D. in Business Administration from Michigan State University. Her research centers on understanding managerial issues in services marketing, innovation and new product development and has been published in the Journal of Product Innovation Management and Cornell Hospitality Quarterly. 